\title{
COMPARATIVE STUDY TO ASSESS THE EFFECTIVENESS OF NEBULIZED 3\% HYPERTONIC SALINE AND NEBULIZED LEVOSALBUTAMOL IN THE MANAGEMENT OF BRONCHIOLITIS
}

\author{
SARA SHIREEN ${ }^{1}$, SAFURA SULTANA ${ }^{1 *}$, KHADIJA AKHTAR OMER ${ }^{1}$, ATIKA BEGUM QUTUB ${ }^{1}$, NARAYAN REDDY U ${ }^{2}$
}

${ }^{1}$ Department of Pharmacy Practice, Deccan School of Pharmacy, Hyderabad, Telangana, India. ${ }^{2}$ Department of Paediatrics, Princess Esra Hospital, Deccan College of Medical Sciences, Hyderabad, Telangana, India. Email: safuraahmed99@gmail.com

Received: 01 May 2020, Revised and Accepted: 05 August 2020

\section{ABSTRACT}

Objective: The objective of the study was to compare the effects of nebulized $3 \%$ hypertonic saline and nebulized levosalbutamol in the management of bronchiolitis.

Methods: Seventy children of age 1-24 months admitted into the hospital with the diagnosis of bronchiolitis. Participants were divided into two groups of 35 each. Group A was given nebulized 3\% hypertonic saline and Group B was given nebulized levosalbutamol. Modified respiratory distress assessment instrument (RDAI) is used at admission, at $48 \mathrm{~h}$ after admission, and at the time of discharge to identify the reduction in scores between two groups.

Results: The mean age of patients in the study population was $10.1 \pm 6.4$ months. The mean birth weight of patients in Group A and Group B was $3.00 \pm 0.61$ and $3.12 \pm 0.75$. The percentage of male patients was $57.1 \%$ and the percentage of female patients was $42.8 \%$. The modified RDAI score in Group A and Group B at admission, $48 \mathrm{~h}$ of admission, and at the time of discharge was 4.34 $\pm 0.87,2.4 \pm 1.03$, and $0.67 \pm 0.05$ (p=0.04) and 4.11 \pm 0.58 , $3.60 \pm 1.00$, and $2.51 \pm 0.96(p=0.12$ ). The hospital stay was observed to be lowered in Group A ( $3.77 \pm 0.88)$ compared to Group B (5.43 \pm 0.92 ; $p=0.04$ ).

Conclusion: From the findings of our study, we conclude that nebulized 3\% hypertonic saline, as it acts by hindering the pathophysiologic mechanism of bronchiolitis, is more effective in reducing the clinical severity score and length of hospital stay. Further $3 \%$ hypertonic saline also have the additional benefit of decreasing the economic burden of disease as it is safe, inexpensive, reduces the inpatient hospital charges by reducing the length of stay.

Keywords: Bronchiolitis, 3\% hypertonic saline, Levosalbutamol, Modified respiratory distress assessment instrument, Nebulization.

(C) 2020 The Authors. Published by Innovare Academic Sciences Pvt Ltd. This is an open access article under the CC BY license (http://creativecommons. org/licenses/by/4. 0/) DOI: http://dx.doi.org/10.22159/ajpcr.2020.v13i10.38103

\section{INTRODUCTION}

Bronchiolitis, an infection of the lower respiratory tract, is a common viral infection affecting the children below 2 years of lifetime. It is the principal cause of hospitalization, with remarkable morbidity and mortality in both advanced and growing countries [1]. The familiar viruses to cause bronchiolitis infection include respiratory syncytial virus, parainfluenza, influenza, rhinovirus, adenovirus, and metapneumovirus and bacteria like Mycoplasma pneumoniae have also been implicated in the etiology of bronchiolitis [2-4]. In general, no complex investigations are required in the diagnosis of bronchiolitis, it is simple based on signs and symptoms [5].

As stated in a report given by the WHO, approximately 150 million new cases of clinical pneumonia (primarily pneumonia and bronchiolitis) occur per annum. Among them, majority 11-20 million be in need of hospital admission [6]. Within the first 2 years of life, more than onethird of children suffer from bronchiolitis, among them 1 out of 10 infants require hospitalization [7,8]. Mortality rate of bronchiolitis is $0.5-1.5 \%$ among hospitalized children which is elevated to $3-4 \%$ in case of children suffering with cardiopulmonary complications [9]. About $95 \%$ of the bronchiolitis cases occur in the growing countries, across the world [6]. Therefore, in India also, it is a significant problem due to high incidence and its associated health and economic impact $[10,11]$.

Treatment of bronchiolitis is many a times infuriating for treating doctor and caretaker because most strategies "doesn't seem to work" in majority of the cases. There is no strong evidence for the various treatment strategies used in the management of bronchiolitis including epinephrine, bronchodilators, steroids, anticholinergics, antibacterials, surfactants, and chest physiotherapy.
The aim of our study was to compare the effects of nebulized $3 \%$ hypertonic saline and nebulized levosalbutamol in the management of bronchiolitis among hospitalized children in Indian setting.

\section{METHODS}

A single-centered prospective study was conducted on 70 children in the pediatric ward of Princess Esra Hospital, Hyderabad, during a period of 6 months.

\section{Inclusion criteria}

All children aged 1-24 months with clinical diagnosis of bronchiolitis were included in the study.

\section{Exclusion criteria}

Children of age $<1$ month and $>24$ months, children with chronic illness such as congenital heart disease, cystic lung disease, immunodeficiency syndrome, and children with preterm birth were excluded from the study.

A written informed consent was taken from the parents on a prescribed format. The study was approved by ethical committee of Deccan College of Medical Sciences, Hyderabad. The data of all cases were recorded on predetermined pro forma for the following characteristics: Age, gender, family history of atopy, temperature, heart rate, and modified respiratory distress assessment score (Fig. 1).

The children were assigned randomly in sequential manner into two groups of 35 each designated as $\mathrm{A}$ and $\mathrm{B}$.

1. Children in Group A were nebulized with $4 \mathrm{ml}$ of $3 \%$ hypertonic saline. 


\begin{tabular}{|c|c|c|c|c|}
\hline $\begin{array}{l}\text { CLINICAL } \\
\text { PARAMETERS }\end{array}$ & SCORE 0 & SCORE 1 & SCORE 2 & SCORE 3 \\
\hline $\begin{array}{l}\text { RESPIRATORY } \\
\text { RATE (PER MIN) }\end{array}$ & $<40$ & $40-60$ & $60-70$ & $>70$ \\
\hline $\begin{array}{l}\text { USE OF } \\
\text { ACCESSORY } \\
\text { MUSCLES* }\end{array}$ & None & $\begin{array}{l}1 \text { accessory } \\
\text { muscle used }\end{array}$ & $\begin{array}{l}2 \text { accessory muscle } \\
\text { used }\end{array}$ & $\begin{array}{l}\geq 3 \text { accessory } \\
\text { muscle used }\end{array}$ \\
\hline COLOR/CYANOSIS & $\begin{array}{l}\text { Pink in room } \\
\text { air/no } \\
\text { cyanosis }\end{array}$ & $\begin{array}{l}\text { Cyanosed } \\
\text { when crying }\end{array}$ & $\begin{array}{l}\text { Pink with oxygen } \\
\text { or cyanosed in } \\
\text { room air }\end{array}$ & $\begin{array}{l}\text { Cyanosed } \\
\text { with oxygen } \\
\text { or cardio- } \\
\text { respiratory } \\
\text { arrest }\end{array}$ \\
\hline $\begin{array}{l}\text { AUSCULTATORY } \\
\text { FINDINGS }\end{array}$ & Normal & $\begin{array}{l}\text { Decreased air } \\
\text { entry, no } \\
\text { rhonchi heard }\end{array}$ & $\begin{array}{l}\text { Decreased air entry, } \\
\text { rhonchi heard }\end{array}$ & Silent chest \\
\hline
\end{tabular}

Fig. 1: Modified respiratory distress assessment score $\left({ }^{*}\right.$ Accessory muscle usage: suprasternal, subcostal, and intercostal retractions; mild bronchiolitis: Score 0-4; moderate bronchiolitis: Score 5-8; severe bronchiolitis: Score 9-12)

Table 1: Distribution of clinical variables between Group A and Group B (n=70)

\begin{tabular}{lllll}
\hline Clinical characteristics & & Group A (n=35) & Group B (n=35) & p value \\
\hline Age (months) & & $9.60 \pm 6.52$ & $10.60 \pm 6.61$ & 0.52 \\
Birth weight (kg) & & $3.00 \pm 0.61$ & $3.12 \pm 0.75$ & 0.43 \\
Male \% & $74.29 \%$ & $40.00 \%$ & - \\
Method of childbirth & Vaginal & $48.57 \%$ & $45.71 \%$ & - \\
Children exposed to passive smoking & Cesarean & $51.43 \%$ & $54.29 \%$ & - \\
& Yes & $28.57 \%$ & $34.28 \%$ & \\
\hline
\end{tabular}

Group A treated with nebulized 3\% hypertonic saline and Group B treated with nebulized levosalbutamol, ${ }^{*} \mathrm{p}<0.05$ is statistically significant

2. Children in Group B were given levosalbutamol nebulization $0.15 \mathrm{mg} / 3 \mathrm{ml}$.

The nebulizations were given 4 times daily till discharge. The modified respiratory distress assessment instrument (RDAI) score was recorded at the time of admission, at $48 \mathrm{~h}$ after admission, and at the time of discharge.

\section{Statistical analysis}

Descriptive statistical analysis was performed, the comparative study of different variables was done by unpaired " $\mathrm{t}$ "-test. One-way ANOVA used to compare modified RDAI scores between two groups. $\mathrm{p}<0.05$ was considered as statistically significant.

\section{RESULTS}

Among 70 patients included in the study, the percentage of male patients was $57.1 \%$ and the percentage of female patients was $42.8 \%$.

The mean age of patients in the study population was $10.1 \pm 6.4$ months. The maximum number of patients belongs to the age group of 1-12 months (78.5\%). The mean birth weight of patients in Group A and Group B was $3.00 \pm 0.61$ and $3.12 \pm 0.75$, respectively (Table 1 ). Our study did not find any significant mean value difference with respect to age and birth weight between Group A and Group B.

About 3\% hypertonic saline nebulization caused significant reduction in the modified RDAI score as compared to levosalbutamol nebulization. The modified RDAI score in nebulized 3\% hypertonic saline and nebulized levosalbutamol at admission, $48 \mathrm{~h}$ after admission, and at the time of discharge was $4.34 \pm 0.87,2.4 \pm 1.03$, and $0.67 \pm 0.05(\mathrm{p}=0.04)$ and $4.11 \pm 0.58,3.60 \pm 1.00$, and $2.51 \pm 0.96(\mathrm{p}=0.12$ ) (Table 2). Modified RDAI score was significantly decreased at $48 \mathrm{~h}$ of treatment and at the time of discharge in Group A patients compared to Group B patients (Table 3).
Table 2: Mean score values of modified respiratory distress assessment instrument between Group A and Group B ( $n=70)$

\begin{tabular}{llllll}
\hline Group & $\begin{array}{l}\text { At } \\
\text { admission }\end{array}$ & At 48 h & $\begin{array}{l}\text { At } \\
\text { discharge }\end{array}$ & F value & p value \\
\hline $\begin{array}{l}\text { Group A } \\
(\mathrm{n}=35)\end{array}$ & $4.34 \pm 0.87$ & $2.40 \pm 1.03$ & $0.67 \pm 0.05$ & 10.58 & $0.04^{*}$ \\
$\begin{array}{l}\text { Group B } \\
(\mathrm{n}=35)\end{array}$ & $4.11 \pm 0.58$ & $3.60 \pm 1.00$ & $2.51 \pm 0.96$ & 2.41 & 0.12 \\
\hline * & & & & & \\
\hline
\end{tabular}

${ }^{*} \mathrm{p}<0.05$ is statistically significant

Table 3: Intergroup comparison of modified respiratory distress assessment instrument score at different stages of treatment $(n=70)$

\begin{tabular}{llll}
\hline $\begin{array}{l}\text { Modified respiratory distress } \\
\text { assessment instrument }\end{array}$ & $\begin{array}{l}\text { Group A } \\
(\mathbf{n = 3 5})\end{array}$ & $\begin{array}{l}\text { Group B } \\
(\mathbf{n = 3 5})\end{array}$ & p value \\
\hline At admission (Mean \pm SD) & $4.34 \pm 0.87$ & $4.11 \pm 0.58$ & 0.14 \\
At $48 \mathrm{~h}($ Mean \pm SD) & $2.40 \pm 1.03$ & $3.60 \pm 1.00$ & $0.05^{*}$ \\
At discharge (Mean \pm SD) & $0.67 \pm 0.05$ & $2.51 \pm 0.96$ & $0.01^{*}$ \\
\hline
\end{tabular}

${ }^{*} \mathrm{p}<0.05$ is statistically significant

There was a significant difference with respect to length of hospital stay between two groups. The hospital stay was observed to be lowered in Group A (3.77 \pm 0.88$)$ compared to Group B ( $5.43 \pm 0.92 ; \mathrm{p}=0.04)$ (Table 4).

\section{DISCUSSION}

In our investigation, the mean age of children was seen as $10.1 \pm 6.4$ months, the youngest being 1.5 months, and the oldest being 2 years. These outcomes are similar with the investigations by Sarrell et al. in which the mean age of patients was noticed as $12.5 \pm 6$ months 
Table 4: Length of hospital stay $(n=70)$

\begin{tabular}{lll}
\hline Group & Hospital stay (Mean \pm SD) & p value \\
\hline Group A $(n=35)$ & $3.77 \pm 0.88$ & $0.04^{*}$ \\
Group B $(n=35)$ & $5.43 \pm 0.92$ & \\
\hline
\end{tabular}

${ }^{*} \mathrm{p}<0.05$ is statistically significant

(range 3-24 months) [12]. In our study, majority of the children $(78.5 \%)$ suffered from bronchiolitis during the $1^{\text {st }}$ year of life. This is in understanding that $80 \%$ of bronchiolitis cases happen during the primary year of life [13].

In our study, $57.1 \%$ of the patients were male and $42.8 \%$ were female, subsequently, the males were more influenced than females. The maleto-female proportion in our investigation was 1.3:1. Comparative discoveries were accounted by Kuzik et al. and Kokero et al. with a male dominance of $62.5 \%$ and $58.6 \%[13,14]$. The $2 \times$ chromosomes in females which give more varieties in the immunogenic safeguard design might be attributed to low frequency of bronchiolitis in females when contrasted with males. In addition, in India, the guardians have progressively health care seeking mentality toward male child [15].

At the point, when the data were delineated concerning mean score estimations of each phase of treatment, modified RDAI score was altogether reduced at $48 \mathrm{~h}$ of treatment and at the time of discharge in Group A patients compared with Group B patients; subsequently, our investigation showed that $3 \%$ hypertonic saline nebulization caused significant decrease in the modified RDAI when compared with levosalbutamol nebulization. This concurs with the results of comparable investigations of Mandelberg et al. and Kuzik et al. [14,16]. A Cochrane review was led in 2013, this review was done with the intention to decide the impact of nebulized 3\% hypertonic saline in patients with acute viral bronchiolitis. The result of this review was nebulized 3\% hypertonic saline fundamentally reduced the length of hospital stay among inpatients and clinical seriousness score logically upgraded in both outpatient and hospitalized children. They additionally discovered that no unfavorable effects are accounted with $3 \%$ hypertonic saline nebulization [17].

With nebulized 3\% hypertonic saline, the modified RDAI score decreased significantly after treatment (i.e., at $48 \mathrm{~h}$ and at the time of discharge). This might be because of interfering activity of $3 \%$ hypertonic saline on the pathophysiologic component of bronchiolitis by decreasing the inflammation, promoting the intracellular debris clearance, and expanding the mucociliary transport.

The mean span of hospital stay in our examination was $3.77 \pm 0.88$ and $5.43 \pm 0.92$ days in nebulized $3 \%$ hypertonic saline and nebulized levosalbutamol groups, respectively, the difference of hospital stay between two groups was significant $(\mathrm{p}=0.04)$. The reduction of hospital stay with nebulized 3\% hypertonic saline either alone or in addition with other drugs is accounted by numerous investigations led by different authors. In Louz et al., the mean length of hospital stay was $6 \pm 1.2$ and $7.4 \pm 1.5$ days in $3 \%$ HS (with salbutamol) and $0.9 \%$ normal saline (with salbutamol), respectively, these outcomes were additionally statically significant $\mathrm{p}<0.005$ [18]. Our investigation has similar perceptions with respect to duration of hospital stay with this study.

\section{CONCLUSION}

From the findings of our study, we conclude that nebulized $3 \%$ hypertonic saline, as it acts by interfering with the pathophysiologic mechanism of bronchiolitis, was more effective in reducing the clinical severity score and length of hospital stay. Further 3\% hypertonic saline also have the additional benefit of decreasing the economic burden of disease as it is safe, cheap, gives a kind of relaxation from the inpatient hospital charges by reducing the length of stay.

\section{AUTHORS' CONTRIBUTIONS}

Dr. U. Narayan reddy and Sara shireen have contributed to conception, design of the study, and statistical interpretation of data. Safura sultana, Khadija Akhtar Omer, and Atika Begum Qutub have contributed in acquisition, conduct of the study, interpretation of data, and preparation of the manuscript.

\section{CONFLICTS OF INTEREST}

The authors declared no conflicts of interest regarding the research, authorship, and publication of this article.

\section{SOURCE OF FUNDING}

Self-funding.

\section{REFERENCES}

1. Chaudhary K, Sinert R. Is nebulized hypertonic saline solution an effective treatment for bronchiolitis in infants? Ann Emerg Med 2010;55:120-2.

2. Handforth J, Friedland JS, Sharland M. Basic epidemiology and immunopathology of RSV in children. Paediatr Respir Rev 2000;1:210-4.

3. Epidemiology of Respiratory Syncytial Virus Infections; 2020. Available from: http://www.virology-online.com/viruses/rsv2.htm. [Last accessed on 2020 Jan 25].

4. Williams JV, Harris PA, Tollefson SJ, Halburnt-Rush LL, Pingsterhaus JM, Edwards KM et al. Human metapneumovirus and lower respiratory tract disease in otherwise healthy infants and children. N Engl J Med 2004;350:443-50.

5. Alexander KC, James DK, Davies HD. Respiratory syncytial virus bronchiolitis. J Natl Med Assoc 2005;97:1708-13.

6. Igor R, Tomaskovic L, Boschi-Pinto C, Campbell H. Global estimate of the incidence of clinical pneumonia among children under five years of age. Bull World Health Organ 2004;82:895-903.

7. Ralston SL, Lieberthal AS, Meissner HC, Alverson BK, Baley JE, Gadomski AM, et al. Clinical practice guideline: The diagnosis, management, and prevention of bronchiolitis. Pediatrics 2014; 134 :e1474-502.

8. Hasegawa K, Tsugawa Y, Brown DF, Mansbach JM, Camargo CA. Trends in bronchiolitis hospitalizations in the United States 2000-2009. Pediatrics 2013;132:28-36.

9. Dennis MM. Bronchiolitis. Arch Dis Child Educ Pract 2005;90:81-6.

10. Yorita KL, Holman RC, Sejvar JJ, Steiner CA, Schonberger LB. Infectious disease hospitalizations among infants in the United States. Pediatrics 2008;121:244-52.

11. Deshpande S, Northern V. The clinical and health economic burden of respiratory syncytial virus disease among children under 2 years of age in a defined geographical area. Arch Dis Child 2003;88:1065-9.

12. Sarrell EM, Tal G, Witzling M, Someck E, Houri S, Cohen HA, et al. Nebulized 3\% hypertonic saline solution treatment in ambulatory children with viral bronchiolitis decreases symptoms. Chest 2002;122:2015-20.

13. Koker O, Ozdogan S, Kose G, Yildirmak Z. Comparison of the efficacies of normal saline versus hypertonic saline in the management of acute bronchiolitis. Int J Contemp Pediatr 2016;3:795-800.

14. Kuzik BA, Al Qadhi SA, Kent S, Flavin MP, Hopman W, Hotte SA, et al. Nebulized hypertonic saline in the treatment of viral bronchiolitis in infants. J Pediatr 2007; 151:266-70.

15. Malik G, Singh A, Singh K, Pannu MS, Singh P, Banga S, et al. A comparative study to assess the effects of nebulised $3 \%, 0.9 \%$ normal saline and salbutamol in the management of acute bronchiolitis among indian children. J Evol Med Dent Sci 2015;4:3662-8.

16. Mandelberg A, Tal G, Witzling M, Somexk E, Houri S, Balin A, et al. Nebulized 3\% hypertonic saline solution treatment in hospitalized infants with viral bronchiollitis. Chest 2003;123:481-7.

17. Zhang L, Mendoza-Sassi RA, Klassen TP, Wainwright C. Nebulized hypertonic saline for acute bronchiolitis: A systematic review. Pediatrics 2015; 136:687-701

18. Luo Z, Liu E, Luo J, Li S, Zeng F, Yang X, et al. Nebulized hypertonic saline/salbutamol solution treatment in hospitalized children with mild to moderate bronchiolitis. Pediatr Int 2010;52:199-202. 